University of Warwick institutional repository

This paper is made available online in accordance with

publisher policies. Please scroll down to view the document itself. Please refer to the repository record for this item and our policy information available from the repository home page for further information.

To see the final version of this paper please visit the publisher's website. Access to the published version may require a subscription.

Author(s): Matthew Watson

Article Title: Constituting Monetary Conservatives via the 'Savings Habit': New Labour and the British Housing Market Bubble Year of publication: 2008

Link to published version: http://dx.doi.org/ 10.1057/cep.2008.12 Publisher statement: This is a post-peer-review, pre-copyedit version of an article published in Comparative European Politics. The definitive publisher-authenticated version, Watson, M. (2008). Comparative European Politics. Constituting Monetary Conservatives via the 'Savings Habit': New Labour and the British Housing Market Bubble, pp. 285-304 is available at http://dx.doi.org/ 10.1057/cep.2008.12 


\title{
Constituting Monetary Conservatives via the 'Savings Habit': New Labour and the British Housing Market Bubble
}

\author{
Matthew Watson \\ Department of Politics and International Studies \\ University of Warwick \\ Coventry, CV4 7AL, UK \\ matthew.g.watson@warwick.ac.uk
}

Published in Comparative European Politics, 6 (3), 2008, 285-304. 


\title{
Constituting Monetary Conservatives via the 'Savings Habit': New Labour and the British Housing Market Bubble
}

\begin{abstract}
The ongoing world credit crunch might well kill off the most recent bubble dynamics in the British housing market by driving prices systematically downwards from their 2007 peak. Nonetheless, the experience of that bubble still warrants analytical attention. The Labour Government might not have been responsible for consciously creating it, but it has certainly grasped the opportunities the bubble has provided in an attempt to enforce a process of agential change at the heart of the British economy. The key issue in this respect is the way in which the Government has challenged the legitimacy of passive welfare receipts in favour of establishing a welfare system based on incorporating the individual into an active asset-holding society. The housing market has taken on new political significance as a means for individuals first to acquire assets and then to accumulate wealth on the back of asset ownership. The ensuing integration of the housing market into an increasingly reconfigured welfare system has permeated into the politics of everyday life. It has been consistent with individuals remaking their political subjectivities in line with preferences for the type of conservative monetary policies which typically keep house price bubbles inflated.
\end{abstract}

Keywords: British housing market; house price bubble; credit crunch; asset-based welfare; super-portfolio; Thatcherism; New Labour 


\section{Introduction}

On May $13^{\text {th }} 2008$ Caroline Flint, Housing Minister in the Brown Government, was photographed in Downing Street on her way to a private Cabinet meeting which had been called to discuss the problems then afflicting the British housing market. ${ }^{1}$ When the photographs were enlarged the contents of her briefing notes were clearly visible and found their way into the next day's newspapers. They contained the warning to her Cabinet colleagues that "we can’t know how bad it will get”, alongside the prediction that prices would fall in the following year by 10\% "at best" (Guardian, 14.05.08). This represented the latest in a long line of bad news stories for an increasingly beleaguered Government seeking sanctuary from the political fallout as the world credit crunch began to affect British house prices.

For the whole of New Labour's first decade in power, the sustained period of significant year-on-year property price increases allowed British households to consume at a rate that exceeded their income from paid work. The additional consumption generated a strong macroeconomic growth performance. Under Gordon Brown's stewardship, the Treasury reacted to these emergent trends by attempting to lock-in the favourable price trajectory on the housing market. To that end, it sought to instil what it described as the 'savings habit' throughout society. The aim has been to provide a guaranteed flow of new entrants into the housing market in order to keep house prices buoyant. The Treasury has been eager to avoid the situation in which property purchases, especially involving first-time homebuyers, are conducted in the absence of savings. This had been the backdrop to the widespread experience of negative equity in Britain in the late 1980s and early 1990s, when falling house prices

\footnotetext{
${ }^{1}$ This piece was written with the financial assistance of a grant from the UK's Economic and Social Research Council (number RES-000-22-2198). I gratefully acknowledge the ESRC's continuing support of my research.
} 
left the market price of many houses significantly below the level of outstanding mortgage repayments, thus contributing to further price falls as entry into the housing market stalled.

The analysis that follows is organized around this key contextual difference between the two most recent experiences of bubble dynamics in British house prices. It is a tale of two distinct bubbles: the most recent one standing out from its predecessor insofar as it inflated in the context of conscious Government action designed to facilitate the savings culture within society. The rapid rise in house prices in Britain in the mid 1980s was a genuine market bubble, because it arose in the absence of direct political interventions aimed specifically at producing the resulting price effects. It was primarily the unintended consequence of the process of financial liberalization. The 'right to buy' initiative, inviting council tenants to purchase their properties at below the market rate, was of course an explicitly political act. It was also an integral part of the cultural politics of ownership in the 1980s. Yet, the selloff was pretty much complete before price increases reached their bubble stage and it also had a very different geography to the local conditions which led prices into that stage.

Viewed comparatively, the more recent price trajectory looks to be more consciously planned - if not at its point of origination then certainly at various points in its continuation. (1) There have been any number of occasions on which fiscal measures could have been called upon to quell the surge in house prices but were deliberately ignored (e.g., Coates 2005: 173). (2) The way in which inflation is measured in Britain has been changed to lessen the impact of the housing market on the calculations which forms the basis of the Monetary Policy Committee of the Bank of England's interest rate decisions (e.g., Keegan 2004: 207-8). (3) The 
microeconomic incentive structure which Brown did so much to reconfigure during his time at the Treasury has been reoriented specifically to facilitate individuals' attempts to ride the back of the bubble (Gibb 2001: 357).

The most important characteristics of the new microeconomic incentive structure relate to New Labour's desire for individuals to become personally responsible for the greater part of their consumption needs in old age. The backdrop to such a wish is the increasing acknowledgement in Government circles that the state pension will not be sufficient in the future to do that for them. The private pension holdings of British people continue to be mainly concentrated in a balance of equities and bonds as selected by their fund managers (e.g., Clark 2000). However, the housing market has been presented as the ideal economic context in which savings in general can be made to grow for the purpose of enabling future consumption. In effect, then, the housing market has been incorporated into a new model of welfare provision at odds with many of the assumptions associated with the post-war British welfare state.

Such a shift has required significant social engineering. In order to deliver a citizenry capable of flourishing in a world of asset-based welfare, the Treasury under Brown set about the task of constituting monetary conservatives. The objective has been to create political subjects who will prevent the Government from introducing macroeconomic conditions which require the type of interest rate rises that burst the 1980s' house price bubble. If the housing market is to be used as the most important element of a system of asset-based welfare, house prices must be protected from interest rate rises. So, the success of such a strategy depends on creating an ever expanding constituency that will not authorize government spending plans financed from current deficits. Insofar as the current threat to British house prices has occurred 
in a context of falling rather than rising interest rates, it could be argued that the policy has been successful in its own terms. However, the effects of the world credit crunch might yet prove a more decisive influence on short-term house prices than those of a macroeconomic regime designed to facilitate their rise.

In order to draw out the comparison between the two most recent British housing market bubbles, the paper proceeds in three stages. In section one, I develop the framework which helps me to make sense of the differences between the two bubble experiences. The crucial contextual factor in this respect is the change in political priorities regarding the management of the welfare state. The overriding goal of the Thatcher Government during the build-up to the 1980s' house price bubble was simply to restrict the scope of existing entitlements. In this sense, the trajectory of house prices was entirely divorced from attempts to recast the whole manner in which welfare was delivered in Britain. By contrast, the overriding goal of the Blair Government in the build-up to the 2000s' house price bubble was to catalyze an increasing shift towards asset-based welfare. Sections two and three subsequently apply the insights arising from the conceptual discussion to the two bubble experiences. Section two focuses on the bubble that burst in the late 1980s, as successive failures of macroeconomic policy in Britain led to the interest rate rises which tightened domestic credit conditions. Section three focuses on the more recent bubble. As of June 2008, this latter bubble has been sheltered from substantial interest rate rises, but its price structure appears to be just as susceptible to the ongoing world credit crunch. 
The Housing Market as 'Two-Dimensional Super-Portfolio’ under Conditions of Asset-Based Welfare

Owner-occupied houses are not priced in Britain today according to a simple valuation technique linked to the costs of providing alternative accommodation and foregoing the standard rate of interest by tying up capital in long-term investments. This would be to under-estimate the prices in evidence throughout the bubble period and often dramatically so. There is now a deeply held sense within British society that activity on the housing market is not merely about providing oneself with somewhere to live. It is also about expecting to be able to cash-in future capital gains, and expectations of that nature form an important part of contemporary house price valuations. Such expectations had a tendency to be self-fulfilling for as long as the bubble remained inflated, thus placing clear upward pressure on actual prices for that period.

Given this, my intention is to develop a conceptual framework which can explain the trajectory of house prices in general as well as draw out both the shared and the separate characteristics of the two most recent British house price bubbles. To begin, it is necessary to shift the focus of most asset valuation techniques, which tends to be on individual assets, so as to concentrate instead on the asset market as a whole. In this case, that means focusing on the housing market as a social institution embedded within the dominant governing strategy of the day. The intuition underpinning such a move is that houses are very rarely valued in isolation and on their own merits, so much as in relation to dominant price trends in the market as a whole. 
Due to the social significance which is attached to owning a property in the 'right' area and being able to trade up to own more expensive properties, individual houses form part of an integrated homeowner investment strategy across society. The dominant price trend in every local segment of the housing market reflects dominant price trends elsewhere and, in this way, individual house prices quickly reflect changes in the price of other houses. As a result, the most important indicator of in which way and by how much the price of an individual house is likely to change is the underlying pattern of price changes in the housing market as a whole.

My explanatory framework rests on the assumption that the prices of individual houses, whilst ostensibly determined independently of one another, in practice exhibit a direct and positive correlation. Indeed, such is the influence of overall market conditions on the price of individual houses that it makes sense to think in terms of the serial correlation of all house prices, at least with respect to local housing markets. Donald MacKenzie has recently pointed to a similar effect in relation to the stock market, where a number of individual stocks have been seen to display price changes which directly replicate one another solely because they are known to form part of the same coordinated investment strategy. He describes the ensuing serial correlation in stock prices as the development of a 'super-portfolio' (MacKenzie 2006: 225, and I intend to use this concept in the remainder of my analysis.

I do so not as a substitute for the notion of a house price bubble but alongside it. A bubble implies a purely speculative price phase in which the psychology of crowds allows individual investors to systematically over-value a particular asset or group of assets (e.g., Shiller 2000). Whilst there is clearly a speculative element to many of the house purchases in both of the episodes described in what follows, this is 
not their only feature. There is also a coordinated element to investments in houses, as individuals seek to 'play the market' by trading up their position within it. The speculative element to price formation does not disappear within such attempts, but it is always set within the context in which conditions in one local housing market shape those in all others. Viewed as a whole, the market is a social phenomenon to the extent that its underlying price trajectory within it reflects the coordinated efforts of individuals to issue social signals through their status as homeowners. By using the concept of a housing market super-portfolio alongside that of a house price bubble, it is possible to capture such a sense of coordination within the speculative price trend. I use the notion of a bubble to apply to a specific trajectory of house prices, whereas I use that of a super-portfolio to apply to the broader features of price coordination within the housing market.

When treating the housing market conceptually as a super-portfolio of serially correlated house prices, a house price bubble can be seen as an asymmetric pricing trend within the super-portfolio. For Governments eager to appropriate the feel-good factor associated with rising house prices for their own electoral ends, the desired pricing trajectory of the housing market super-portfolio is one of continued increases. New Labour has given exactly the same impression as its Conservative predecessor from the 1980s of wanting to claim political credit for presiding over a sustained period of house price rises. Yet, where it has differed has been in its attempts to such rises against macroeconomic disturbance by introducing extra-economic obstacles to the development of self-propelling downward pressure on market valuations. The greater the institutionalization of extra-economic protection the more robust house price bubbles are likely to be, due to the absence of macroeconomic conditions that might otherwise threaten to undermine them. 
Of course, this is not the same as saying that any degree of extra-economic support against macroeconomic disturbance necessarily renders a house price bubble stable. Current conditions in Britain at the time of writing - June 2008 - indicate this only too well. Whilst a faltering macroeconomic position can lead to housing market distress via increased interest rates, the causal relationship between the two can just as easily work in the opposite direction in the absence of any noticeable change in the interest rate stance. If confidence in the housing market temporarily evaporates, as appears to be the case at the moment, this can have a pronounced negative macroeconomic effect, even in the context of the interest rate reductions recently introduced by the Bank of England.

In other words, there is more than one way for house price bubbles to deflate. They can fall prey to a weakening macroeconomic position when a sudden tightening of domestic credit is used as a corrective for general price inflation. This is the outcome that extra-economic support for macroeconomic stability is designed to overcome. Irrespective of the success of introducing such support, however, house price bubbles can also fall prey to exogenous shocks which are unrelated to domestic macroeconomic conditions. The ongoing impact on British house prices from the world credit crunch which began in the summer of 2007 seems to fit this latter scenario.

These, then, are the analytical parameters of the argument that I will employ in the rest of the article as a means of comparing the content of the two most recent British house price bubbles. The later bubble appears to stand out from its predecessor insofar as it would seem to enjoy additional sources of extra-economic protection. This is what lends the later bubble the impression that its continuation has been consciously thought through as a matter of Government strategy. New Labour's 
efforts to enforce agential change in the constitution of monetary conservatives help to institutionalize the macroeconomic conditions consistent with the continuation of the bubble. At the same time, though, it has been unable to do anything to protect the bubble from exogenous shocks originating from within the world credit system.

(1) The housing market super-portfolio that developed bubble features in the late 1980s experienced very little, if any, extra-economic protection designed to shelter it from instability in the macroeconomic regime. In the main, the extraeconomic impacts on pricing trends were limited to the way in which the ideological basis of Thatcherism had permeated everyday life. This in itself was a far from inconsequential matter, the result being the widespread incorporation of individuals into the practices of popular capitalism, as sustained by the ideological imagery surrounding the notion of 'ownership' (e.g., Hall 1983). However, the principles of popular capitalism, on their own, provided no defence against the adverse price effects on the housing market super-portfolio of the interest rate rises that occurred in the late 1980s. The housing market boom had been activated as a consequence of financial liberalization, but the liberalizing trend itself made house prices more susceptible to the turn-down in macroeconomic conditions.

(2) By contrast, the extra-economic protection for the British housing market bubble of the 2000s appears to be much better developed as a means of creating macroeconomic conditions suited to its continuation. The housing market superportfolio associated with the later bubble drew sustenance from the ideology of homeownership, just like the earlier one. But this was also augmented by a more coercive mechanism linked to state retreat in the provision of welfare-enhancing resources for facilitating future consumption possibilities. The release of statesponsored transfer payments to people in old age could once be relied upon to cover 
the larger proportion of consumption needs at that time of life, with bank-based savings covering the remainder. However, reductions in the value of the state pension, coupled with the increasing demand for the individual to assume responsibility for the costs of care in old age, have increasingly rendered redundant this model of welfare (e.g., Pierson 1998). In its place, the Labour Government has championed the move towards a new asset-based model of welfare (e.g., HM Treasury 2000, 2003). The aim of such a move is to encourage individuals to invest in assets at a point in the life cycle when current income is more than enough to sustain current consumption needs. On the proviso that these investments are in strongly performing assets, they can then be cashed-in as an expanded pool of savings to meet consumption needs in old age when current income is insufficient to do so. The housing market was used throughout New Labour's first ten years in power as the primary means for securing such assets.

In effect, what has been created is a 'two-dimensional super-portfolio', in which one dimension relates to the serial correlation of asset-based wealth held in the housing market and the other dimension relates to the serial correlation of house prices themselves. The integration of the housing market into the welfare model links one household's ability to support their own consumption in old age to other households' ability to do likewise, at least insofar as all are attempting to expand their asset-based wealth through homeownership. As such, it should be clear just how much is at stake for the Brown Government at the time of writing, as confidence in the prevailing price structure of the British housing market continues to ebb. The whole of the Government's programme of welfare reform is now increasingly dependent on reproducing a stable and predictable pricing trajectory on the housing 
market. If house prices collapse then its strategy for incorporating people into an asset-based system of welfare looks unlikely to be successful.

The integration of the housing market into the welfare model acts as an extra line of defence for house prices, but only in certain circumstances. It does nothing to lessen the susceptibility of house prices to exogenous shocks whose origins lie in the world credit system. It only offers protection against the interest rate rises which deflate housing bubbles through the temporary tightening of domestic credit conditions. The increasing entrenchment of the second dimension of the later housing market super-portfolio makes it much less likely that social conditions will arise which subsequently lead to a change in domestic monetary policy of this nature. In general, sharp interest rate rises occur after a period of loose monetary policy, and this in turn tends to follow prior popular political mobilization to an expansionary macroeconomic policy. However, the move to an asset-based model of welfare makes this type of political mobilization, ceteris paribus, much less likely.

Given an appropriate degree of financial education, those people with savings invested in assets will know that the future value of their wealth holdings will be jeopardized by the interest rate response to previous periods of loose monetary policy. As such, it is to be expected that they will resist mobilization to such a policy in the first place. The very act of holding assets as a means of financing future consumption renders individuals increasingly open to political pressures for reconstituting themselves as monetary conservatives. Should they act upon these pressures in any widespread manner then the social conditions which lead to subsequent interest rate rises are unlikely to arise. As such, the macroeconomic conditions which create adverse impacts on the trajectory of house prices are less likely to be forthcoming than in the absence of societal demands for strict counter-inflationary policies. 
The extent to which individuals have been reconstituted as monetary conservatives is reflected in the degree to which underlying macroeconomic conditions support the continuation of bubble dynamics in house prices. In turn, it also reflects the prior extent to which the housing market has been incorporated within the model of welfare. The remaining sections of the paper seek to shed light on these propositions by examining the two most recent British housing market bubbles and by showing how the first was unrelated to changing norms of welfare provision but the second was integrally embedded in such changes.

\section{Bubble Number 1: The British Housing Market in the 1980s}

When the Conservatives came to power in 1979, the structure of housing tenure in Britain divided pretty much along class lines. Homeownership was concentrated amongst the middle class and local authority renting amongst the working class. As James Cronin argues (2004: 209), there was a noticeable lack of mobility between the two housing classes because both relied to a considerable extent on the state to secure their tenure. The rents on local authority housing were directly subsidized, and the widespread use of mortgage interest tax relief provided a similar degree of subsidization, albeit less directly, for owner-occupiers. The pattern of state expenditures thus entrenched individuals into particular housing classes on the assumption that housing was a merit good and should therefore be integrated into state provision of a minimum standard of living (Malpass 1996: 463). The reforms to housing policy introduced by the Thatcher Governments were designed specifically to alleviate 'entry' constraints affecting owner-occupation and thus to create genuine 
market conditions for homeownership (Ford and Wilcox 1998: 625) In effect, they were intended to change the whole conception of housing from a merit good to an individualized investment vehicle capable of generating private wealth.

On their own, though, the reforms do little to explain either the subsequent trajectory of house prices in the mid 1980s or the specific content of the house price bubble that ensued. These came about as the unintended consequence of setting the new policy within the context of extensive changes to the financial system, all of which promoted widespread liberalization. It was these changes that fundamentally altered conditions on the supply-side of the mortgage lending market, relaxing entry constraints for many families who had previously been financially excluded from owner-occupation. It was the creation of more and more potential homeowners as a result of a large increase in available mortgage credit which represents the most important factor in the general upward trajectory in house prices in this period.

The Thatcher Government's financial liberalization programme had two main goals. The first was to undermine the embedded monopoly interests that had developed within the financial economy by exposing them to the disciplining effects of price competition. The second was to ensure that the free working of the price system allowed sufficient encouragement to financial entrepreneurs to introduce innovative investment products. Both of these impacts were apparent in the restructuring of the supply-side of the British mortgage lending market in the 1980s.

(1) The Thatcher Government overturned the privileged position of the building societies in providing personal finance for house purchases. In the early 1970s, the Heath Government granted cartel rights in the mortgage lending market to the Building Societies Association in return for the latter pegging the mortgage rate below the prevailing rate of interest (e.g., Grady and Weale 1986). The cartellized 
regime thus created the conditions for relatively cheap mortgages, but this came at the cost of rationing the number of mortgages that could be made available. Thatcherite policy changed all this by the mid 1980s, most notably by lifting restrictions on the retail banks which had previously prevented them from operating mortgage lending businesses (e.g., Buckle and Thompson 1995).

Three effects ensued for the housing market. First, the deregulation process vastly increased households' choice of mortgage provider. The entry of banks onto the traditional terrain of the building societies resulted in less rationing of mortgage credit. Second, greater price competition in the mortgage lending market increased the number of people who could afford to buy any particular house that came available on the open market. The heightened level of mortgage credit consequently fed through into a higher general level of house prices. Third, the introduction of genuine price competition into the mortgage lending market increasingly tightened the link between the mortgage rate and the underlying rate of interest. Mortgage providers were able to recycle their capital within world markets, but this tied their business to world interest rates, and the success of their operations thus became dependent on the differential between world and British interest rates. When British interest rates went up relative to the world rate, mortgage lenders were able to defend their business only by passing on the interest rate rises to borrowers in the mortgage market.

(2) At the same time, the scope of feasible mortgage lending strategies widened due to the effects of a new process of mortgage securitization. Under such a process, the lender's exposure to a number of borrowers is bundled together into a single asset. The purchase of the mortgage-based asset, usually by a private equity fund created especially for the purpose, is financed by the issue of a relatively low- 
risk security constructed against the initial borrowers successfully meeting their mortgage repayments. The probability of a mass default on repayments is significantly lower than the probability of a default on any single repayment. The process of mortgage securitization consequently allows mortgage lenders to increase their exposure to the lending market without having to internalize a commensurable increase in risk (e.g., Langley 2006). The banks cannot avoid credit risk altogether, but the profits they make from transaction fees in the securitization process offset an element of that risk and therefore enhance their overall balance sheet position.

In Britain, the process of mortgage securitization has historically concentrated on the repayment schedules of 'prime loan' borrowers (Council of Mortgage Lenders 2000). Yet, the very essence of the securitization technique is to shift the whole basis of what is presumed to be a 'marginal' lending case in both the prime and the nonprime sector. Securitization therefore provides entry into all segments of the mortgage lending market for people who would otherwise be treated as unacceptable credit risks for that particular segment. It thus expands the pool of potential homebuyers at a faster rate than additions to the supply of housing stock come onstream. This has the effect of feeding upward price pressures in the housing market as a whole.

The combination of mortgage securitization techniques and the introduction of genuine price competition amongst mortgage providers fundamentally altered prevailing supply-side conditions in the mortgage lending market in Britain in the 1980s. Whilst the previous building societies' cartel had led, in effect, to the rationing of new mortgages, the overall effects of financial deregulation created equally clear conditions of over-supply (Taylor and Bradley 1994: 369). A house price boom ensued as mortgage providers over-lent to an increasingly buoyant 
housing market in the context of constrained supply of new housing stock (Wood and Capie 1996: 21).

The results were dramatic. Adjusting for the effects of inflation, real house prices almost doubled between 1983 and 1989. From 1985 to 1988, the annual average percentage price rise of all houses was never less than double digits and, for 1988 alone, the figure was 24\% (Malpass 1996: 465). Such rises made house purchases and, by implication, mortgage lending increasingly unaffordable as a proportion of income, but this occurred at exactly the moment that ever greater numbers of people were being enticed to enter the market - ironically, by the allure of those self-same higher house prices.

This was a house price bubble created specifically as a market phenomenon based on changing conditions of mortgage lending. Serial correlation in house prices emerged from the reform of the supply-side of the mortgage lending market, but there was no attempt to forge an increasingly interdependent relationship between the trend in house prices and internal changes to the welfare state. Throughout the British housing market bubble of the 1980s, the emergent housing market super-portfolio enjoyed almost nothing by way of extra-economic protection against a faltering macroeconomic position arising from welfare reform. There was only a onedimensional, not a two-dimensional, housing market super-portfolio in this period. The Thatcher Government operated its macroeconomic and housing market policies as distinct entities.

Being a purely market-based phenomenon, the 1980s' house price bubble was inherently susceptible to changes in market conditions emerging from instability in the macroeconomic regime. These duly arose. The Lawson Boom of the mid 1980s occurred against the backdrop of convergence between British and world interest 
rates. In 1985, this pushed mortgage rates below $10 \%$ for the first time in over a decade, consequently providing an extra boost for individuals to enter the mortgage borrowing market, either as first-time buyers or in the hope of trading-up their position on the housing market.

Yet, as David Smith has argued (1992: 166), British monetary policy was essentially anchorless at this time. The credit-fuelled consumption boom of the Lawson years stoked retail price inflation. Having fallen from a high of over $20 \%$ in the early 1980s to below $8 \%$ as house prices really began to take off in the mid 1980s, inflation climbed back well into double digits as the decade ended. Lacking an alternative for suppressing inflationary tendencies, the Government had little choice but to respond by raising British interest rates above world market levels (e.g., Pollard 1992: 386-8). The ensuing rise in interest rates triggered accompanying rises in mortgage rates, as the two were now closely tied following the Government's concerted attempts to introduce genuine price competition into the mortgage lending market.

Unsurprisingly, the combination of increasing retail price inflation, increasing mortgage rates and then overall economic recession proved to be a destabilizing cocktail for house prices. They fell increasingly sharply as the recession took hold, propelling the economy into an increasingly vicious cycle of recession and house price falls. Every reduction in house prices increased the real burden of credit repayments as a proportion of income for indebted households. This led to cutbacks in current consumption. But every reduction in current consumption deepened the recession and, with it, deepened also the falling confidence that was already adversely affecting house prices. Average house prices fell by around a quarter between 1989 and 1992 (Audas and MacKay 1997: 869). 
The worst affected people were those who had taken out new mortgages most recently in an attempt to improve their homeowner status. As a reflection of the dramatic surge in house prices from 1985 to 1988, in general they held the highest value mortgages as a proportion of current income. When the overall effect of negative equity peaked in the third quarter of 1992, 99\% of households so affected had taken out a mortgage between 1988 and 1991. In total, this amounted to more than one-in-five homebuyers during that period (Gentle, Dorling and Cornford 1994: 191). The introduction of genuine price competition into the mortgage lending market saturated it with potential supply and, coupled with the effects of securitization, persuaded many lenders to issue mortgages to support house purchases that were backed by little, or even no, cash down-payments. The households most protected from the experience of negative equity were those who had made the largest cash down-payments on their house purchase out of accumulated savings. Two-thirds of house purchases with a 100\% mortgage advance between 1988 and 1991 led to the experience of negative equity by the third quarter of 1992. This figure fell to around one-third for house purchases backed by a $10 \%$ deposit and only one in a thousand for house purchases backed by a 30\% deposit (ibid.: 192).

The negative equity trap was responsible for further chasing house prices downward and, as confidence in the pricing structure of the market as a whole eroded, serial downside correlation ensued. In both phases of the bubble, the prices of individual houses were affected most obviously by the average price of houses in the market overall. The most important feature of the housing market super-portfolio in this period was that its internal characteristics and pricing trajectory were shaped almost solely by institutional changes to the supply-side of the mortgage lending market. The fact that there was no clearly visible extra-economic dimension to the 
super-portfolio made serial downside correlation in house prices just as likely as serial upside correlation. Throughout its life, the bubble remained susceptible to credit shocks arising from domestic macroeconomic conditions.

\section{Bubble Number 2: The British Housing Market in the 2000s}

Looking simply at the trajectory of house prices, the most recent British housing market bubble replicates many of the features of its predecessor. Indeed, the price increases for the most extreme year of the earlier bubble, 1988, are almost directly mirrored year-on-year for the three-year period between 2002 and 2004 (Coates 2005: 171). Since that time a noticeable reduction in the rate of increase has occurred, to the point at which the Housing Minister's industry experts have predicted a $10 \%$ fall in the year from May 2008. If this prediction comes to pass then the magnitude of the fall will be in line with that of 1989 and 1990.

None of these apparent echoes of the former situation mean, however, that the two bubble experiences are generically the same, despite the fact that both arose from a political context emphasizing housing as a means of accumulating private wealth rather than as a social right. The earlier one was a purely market-based phenomenon, whilst the continuation of the latter has been tied much more closely to matters of political strategy. The core substantive features of the earlier one were focused on changes in the supply-side of the mortgage lending market, whilst those of the latter were focused on changes in the demand-side of the mortgage lending market.

The negative equity of the 1980s was experienced most acutely amongst borrowers who had purchased houses on the basis of very little or even no cash 
deposit. The bubble was created in the first place on the supply-side of the mortgage lending market, but its downside price phase was initiated through a seizure on the demand-side of that market, as asset-poor borrowers were exposed by falling house prices. By comparison, New Labour's designs for an asset-based system of welfare have offered a degree of protection for the demand-side of the mortgage lending market. The current difficulties have arisen instead as a result of the world credit crunch having undermined the prior strength of the supply-side of that market. The Government's wish for individuals to become active asset-managers emphasizes the advantages of entering the housing market from the basis of already having accumulated assets. The surest defence against experiencing negative equity when house prices turn down arises from the buffer that comes with having paid a cash deposit on the house. The closer that the mortgage advance comes to $100 \%$ of the original purchase price, the smaller is the required decline in price before the household is subjected to negative equity. Savings thus become significant.

Towards the end of its first term the Labour Government set itself the task of facilitating saving in an attempt to encourage people to create an asset base for themselves (e.g., HM Treasury 2001b). This has particularly been the case amongst the low income families who are usually those that lack assets. The policy has been enacted through a combination of moral directive ('do not be responsible for passing on impeded life chances to your children by depriving them of an inherited asset base'), fiscal incentives ('why bother to pay taxes on a proportion of income that can be invested tax-free in special savings accounts?') and government intervention ('if you can begin to build an asset base for someone previously denied access to one then the government will match your savings out of the public purse'). Alan Finlayson attributes New Labour's savings policy to “a social democratic paternalism” (2008: 
98): one whose specific character is aimed at reconstituting the outlooks, values and economic subjectivities of people who were previously distanced from the savings habit (HM Treasury 2001b: 7; HM Treasury/Inland Revenue 2003: 22). The state under New Labour does little to reward the passive recipients of social rights, focusing instead on trying to support active individuals, incentivizing and even coercing that activity if necessary.

The centrepiece of New Labour's savings policy has been the introduction of the Child Trust Fund, whereby savings accounts are opened by the Inland Revenue through the gift of a so-called 'baby bond' paid out of public taxation (e.g., Wikeley 2004; Gregory and Drakeford 2006). The policy ticks all of New Labour’s boxes. (1) It reduces the number of people who have no assets at all. (2) It locks up savings for the long-term, allowing assets to accumulate before they can be cashed-in. (3) It assists in engaging individuals with financial education designed to make them more attentive to the fact that they cannot rely on the state to finance their consumption in old age. (4) It provides individuals with a material stake in accepting personal responsibility for their future welfare needs.

The Child Trust Fund policy contains within it coercive mechanisms designed to attack a political culture in which individuals consider themselves to be the passive recipients of welfare rights (Finlayson 2008: 96). One aspect of this has been the introduction of programmes aimed not only at increasing everyday financial literacy but also to use that literacy training as a means specifically of adapting more individualized understandings of the self. The establishment of the Funds has been accompanied by placing financial literacy on the National Curriculum in British schools (HM Treasury 2001a: 19). As part of their formal schooling, then, children are now taught how to manage their own assets, what they should expect to earn as a 
return on their assets and how they should proceed to spend their accumulated wealth in a prudent, asset-enhancing fashion. The schoolroom is therefore being used as a means of formally constituting perceptions of the self as a saver, an investor and an active participant in an asset-owning society. Importantly, these are activities which place people in a purely individualized environment, in which they are abstracted from the collective provision of state welfare and concentrate instead on accepting personal responsibility for meeting consumption needs in old age.

The individual savings accounts established by Child Trust Funds are set up in the child's name to enhance the child's sense of ownership of the assets. However, learning how to be a responsible saver is envisioned as a family affair (HM Treasury 2001b: 16). The Treasury pushed for the establishment of the Adult Financial Literacy Advisory Group, which was founded in 2000 to report to the-then Department for Education and Skills. It was to be used as a means of ensuring that a culture of saving was integrated into every aspect of the Government's active welfare programme through enabling lifelong learning of a financial nature (e.g., Froud et al 2007). The Treasury also introduced the New Deal reforms, not only to provide a route back into work for parents but also to promote an understanding of how best they might invest the proceeds that arise from undertaking paid work (e.g., Sunley, Martin and Nativel 2006).

The image that the Government had in mind was of inter-generational financial learning in which the whole family joins together in ensuring that all generations are able to take care of their own future consumption needs (HM Treasury 2000: 23; HM Treasury 2001a: 18; HM Treasury/Inland Revenue 2003: 10). The penalty for failing to do so is to relegate the household to a position in which it has inadequate cover to maintain existing consumption levels throughout the life cycle. 
The Labour Governments of Blair and Brown have thus been prepared to embrace the qualitative limits imposed on the welfare state by their Thatcherite predecessors and to deepen the disciplinary effects designed to ensure that individuals accommodate themselves to those limits. This is likely to lead to more and more people displaying individualized political values.

Of course, such values have multiple roots, so it is highly unlikely that there will be a simple one-to-one relationship between the degree of asset ownership and political attitudes. But it is also largely unthinkable that no effect on policy preferences will be forthcoming in situations in which individuals have both a greater value of assets to defend and a greater reason to wish to defend them because of the declining real worth of the state pension and the need to make good the ensuing deficit through personal wealth. Put simply, if individuals have more assets then they are likely to want to defend them politically. Homeownership dominates wealth holdings in Britain to such an extent that the defence of asset-based wealth is, to a large degree, the defence of house prices. But the prevailing super-portfolio of house prices can only be given protection against the effects of macroeconomic instability on domestic credit conditions, and only then through the institutionalization of a conservative monetary policy. As the Treasury has argued (2000: 11), “People need to be able to save without fear that the value of their savings will be eroded by rapidly rising prices [i.e., consumer prices]". It is likely, then, that the incorporation of individuals into an asset-based system of welfare centred on increasing house prices will facilitate the political remaking of individuals as monetary conservatives.

Responsibility for policing the policy regime that reproduces inflated house prices has therefore been passed on from government to society. This is consistent with the prevailing idea that housing is in any case a means of accumulating private 
wealth rather than a right drawn against the state. New Labour has continually asked to be judged on its success in creating a low-cost credit environment in which interest rates are held in check by credible counter-inflationary performance (e.g., HM Treasury 2006). That success has been difficult to question. The interest rate record of New Labour's first ten years in office was a definite spur for activity on the British housing market.

However, for the same ostensibly virtuous circle to be guaranteed for the future, it must be the case that the health of the housing market depends on nothing other than individuals' material interest in buoyant house prices continuing to generate demands for strict counter-inflationary policies. So long as the British economy can withstand exogenous shocks, the constitution of monetary conservatives does make it more likely that interest rates can be managed without any sharp spikes, as monetary conservatives will be less resistant to pre-emptive strikes against latent inflationary tendencies. Yet, as current circumstances demonstrate only too clearly, this is a very big proviso. The housing market will almost certainly be a beneficiary of the remaking of political subjectivities in line with monetary conservatism, but only when the sole threat to house prices has its origins in domestic macroeconomic conditions. It can never be enough on its own to protect the housing market superportfolio against all exogenous shocks.

The housing market situation under New Labour is rather more complex than a pure price bubble originating solely from the internal dynamics of the supply-side of the mortgage lending market. The extra-economic dimension associated with the integration of the housing market into an asset-based system of welfare is every bit as important for our understanding of the upward price phase as its economic dimension. The current situation could not have arisen in the way it has in the absence of the 
Government's concerted attempts to change the model of welfare provision in Britain to one that emphasizes the personal ownership of assets. Yet, this cannot guarantee that the impact of the ongoing world credit crunch will not unwind the current structure of prices in the same way as if it was indeed a pure price bubble.

\section{Conclusion}

It is always misguided to try to generalize from current pricing trends in the midst of an asset market bubble, and any such attempt would represent extreme recklessness at the time of writing, now that the British housing market bubble is embroiled in the fallout from the world credit crunch. What I have tried to do instead is to compare the two most recent experiences of house price bubbles in Britain in order to isolate their distinctive features. The key difference between the two housing market super-portfolios lies in the introduction into the latter of a noticeable interdependence between the housing market and welfare reform. The family home is increasingly seen as an investment for the future, and this perception has been appropriated in attempts to turn people from passive recipients of welfare rights into active managers of assets. Within this context, serial downside correlation in house prices is less likely now than in the 1980 s as a reaction to monetary policy correctives to macroeconomic instability - albeit only as a reaction to such events. The British housing market remains as vulnerable as it ever has been to exogenous shocks emanating from the world credit system.

The distinctiveness of the most recent bubble can be reflected back onto the important debate between Jim Kemeny and Francis Castles which is outlined in 
Schwartz and Seabrooke's introduction to this issue. Castles's position (1998) that the housing market has been reconfigured politically as 'social policy by other means' appears at first glance to be confirmed by my study of the growing interdependence between the housing market and welfare provision. However, it fails to capture the details of the recent British experience. There is more to the changing relationship between the housing market and the welfare state in Britain than that increasingly they are functional equivalents. The incorporation of the housing market as a constitutive feature of the welfare system suggests that the relationship between the two is more integrally formed than Castles's position allows. Crucially, it involves changing the perceptions and the political preferences of voters. This brings me closer to the work of Kemeny (1980), but my analysis does no more than offer partial confirmation of his thesis. Kemeny believed that the changing subjectivities of homeowning voters restricted the scope of the welfare state via the tax system, but the causality I have in mind operates instead via preferences for increasingly conservative monetary policies.

Yet, this is not to claim that either Castles or Kemeny are wrong on the central premise about private homeownership on which they agree. The recent British experience is clearly cast in the image of their assertion that the money which individuals need to set aside for down-payments and mortgage costs impacts adversely on the likely success of trying to sell politically the merits of a fully-funded state-sponsored system of welfare. This is the 'welfare trade-off' described by Schwartz and Seabrooke in the introduction. Indeed, in the British case, the welfare trade-off was noticeably tightened at each stage that the most recent bubble ratcheted up both affordability and accessibility constraints. The Royal Institution of Chartered Surveyors (2007) has shown that the generic affordability of private housing stock in 
Britain - measured as the proportion of take-home pay required to meet mortgage repayments - returned in 2007 to the record levels of 'unaffordability' witnessed during the collapse of the 1980s' bubble. On top of that, the generic accessibility of private housing stock in Britain - measured as the proportion of take-home pay required to meet the up-front costs associated with house purchases - far outstripped previous record levels of ‘inaccessibility’ at its 2007 peak.

The Labour Government might not have been responsible for deliberately engineering the onset of the most recent bubble, but it has certainly staked much on its continuation. New Labour's ability to guide the economy successfully through a period of welfare reform appears to be dependent upon the vitality of the housing market, as does its political popularity. The increasing unaffordability and inaccessibility of private housing stock in Britain spells trouble for the Government in both these respects. Yet, this might still pale into insignificance against the effects on house prices of the world credit crunch.

\section{References}

Audas, Richard and MacKay, Ross (1997) 'A Tale of Two Recessions', Regional Studies 31(9): 867-874.

Buckle, Mike and Thompson, John (1995) The UK Financial System: Theory and Practice, $\left(2^{\text {nd }}\right.$ edn), Manchester: Manchester University Press.

Castles, Francis (1998) 'The Really Big Trade-Off: Home Ownership and the Welfare State in the New World and the Old', Acta Politica 33(1): 5-19. 
Clark, Gordon (2000) Pension Fund Capitalism, Oxford: Oxford University Press.

Coates, David (2005) Prolonged Labour: The Slow Birth of New Labour Britain, Basingstoke: Palgrave Macmillan.

Council of Mortgage Lenders (2000) UK Will Continue to Lead Mortgage Securitisation in Europe, London: Council of Mortgage Lenders.

Cronin, James (2004) New Labour's Pasts: The Labour Party and Its Discontents, Harlow: Pearson.

Finlayson, Alan (2008) 'Characterizing New Labour: The Case of the Child Trust Fund', Public Administration 86(1): 95-110.

Ford, Janet and Wilcox, Steve (1998) 'Owner Occupation, Employment and Welfare: The Impact of Changing Relationships on Sustainable Home Ownership', Housing Studies 13(5): 623-638.

Froud, Julie, Leaver, Adam, Williams, Karel and Zhang, Wei (2007) ‘The Quiet Panic about Financial Illiteracy', in Libby Assassi, Anastasia Nesvetailova and Duncan Wigan (eds.) Global Finance in the New Century: Deregulation and Beyond, Basingstoke: Palgrave Macmillan.

Gentle, Christopher, Dorling, Daniel and Cornford, James (1994) 'Negative Equity and British Housing in the 1990s: Cause and Effect', Urban Studies 31(2): 181-199.

Gibb, Kenneth (2001) 'Helping with Housing Costs? Unravelling the Political Economy of Personal Subsidy', in David Cowan and Alex Marsh (eds.) Two Steps Forward: Housing Policy Into the New Millennium, Bristol: Policy Press.

Grady, John and Weale, Martin (1986) British Banking 1960-1985, London: Macmillan. 
Gregory, Lee and Drakeford, Mark (2006) 'Social Work, Asset-Based Welfare and the Child Trust Fund', British Journal of Social Work 36(1): 149-157.

Hall, Stuart (1983) 'The Great Moving Right Show', in Stuart Hall and Martin Jacques (eds.) The Politics of Thatcherism, London: Lawrence and Wishart.

HM Treasury (2000) Building Long-Term Prosperity For All: Pre-Budget Report, London: HM Treasury.

HM Treasury (2001a) Saving and Assets For All: The Modernisation of Britain's Tax and Benefit System, Number Eight, London: HM Treasury.

HM Treasury (2001b) Delivering Saving and Assets: The Modernisation of Britain's Tax and Benefit System, Number Nine, London: HM Treasury.

HM Treasury (2003) 'Child Trust Fund Proposals Published', www.hmtreasury.gov.uk.

HM Treasury (2006) Pre-Budget Report 2006, London: HM Treasury.

HM Treasury/Inland Revenue (2003) Detailed Proposals for the Child Trust Fund, London: Her Majesty’s Stationery Office.

Keegan, William (2004) The Prudence of Mr Gordon Brown, Chichester: John Wiley \& Sons.

Kemeny, Jim (1980) 'Home Ownership and Privatisation', International Journal of Urban and Regional Research 4(3): 372-388.

Langley, Paul (2006) 'Securitising Suburbia: The Transformation of Anglo-American Mortgage Finance’, Competition and Change 10(3): 283-299.

MacKenzie, Donald (2006) An Engine, Not a Camera: How Financial Models Shape Markets, Cambridge, MA: MIT Press.

Malpass, Peter (1996) 'The Unravelling of Housing Policy in Britain', Housing Studies 11(3): 459-470. 
Pierson, Christopher (1998) Beyond the Welfare State? The New Political Economy of Welfare (revised edn), Cambridge: Polity.

Pollard, Sidney (1992) The Development of the British Economy, 1914-1990 (4 ${ }^{\text {th }}$ edn), London: Edward Arnold.

Royal Institution of Chartered Surveyors (2007) RICS Housing Accessibility and Affordability Update for Great Britain, London, RICS.

Shiller, Robert (2000) Irrational Exuberance, Princeton, NJ: Princeton University Press.

Smith, David (1992) From Boom to Bust: Trial and Error in British Economic Policy, London: Penguin.

Sunley, Peter, Martin, Ron and Nativel, Corinne (2006) Putting Workfare in Place: Local Labour Markets and the New Deal, Oxford: Blackwell.

Taylor, Jim and Bradley, Steve (1994) 'Spatial Disparities in the Impact of the 199092 Recession: An Analysis of UK Counties', Oxford Bulletin of Economics and Statistics 56(4): 367-382.

Wikeley, Nick (2004) 'Child Trust Funds - Asset-Based Welfare or a Recipe for Increased Inequality?’, Journal of Social Security Law 11(4): 189-224.

Wood, Geoffrey and Capie, Forrest (1996) 'Debt, Deflation and Economic Policy’, Review of Policy Issues 2(1): 15-26. 